\title{
Virus-Induced Gene Silencing in Transgenic Plants Expressing the Minor Capsid Protein of Beet western yellows virus
}

\author{
V. Brault, S. Pfeffer, M. Erdinger, J. Mutterer, and V. Ziegler-Graff \\ UR-BIVV, INRA, 28 rue de Herrlisheim 68021 Colmar, Cedex, France; IBMP, CNRS, 12 rue du Général Zimmer 67084 \\ Strasbourg, Cedex, France
}

Submitted 29 December 2001. Accepted 19 April 2002.

\begin{abstract}
Transgenic Nicotiana benthamiana expressing the minor coat protein P74 of the phloem-limited Beet western yellows virus (BWYV) exhibited an unusual spatial pattern of posttranscriptional gene silencing (PTGS) when infected with BWYV or related viruses. Following infection, transgenic P74 and its mRNA accumulated to only low levels, 21 to 23 nucleotide RNAs homologous to the transgene appeared, and the transgene DNA underwent methylation. The infecting viral RNA, however, was not subject to significant silencing but multiplied readily and produced P74 in the phloem tissues, although the P74 encoded by the transgene disappeared from the phloem as well as the nonvascular tissues.
\end{abstract}

Additional keywords: polerovirus, virus-induced gene silencing.

Posttranscriptional gene silencing (PTGS) in plants is a homology-dependent RNA degradation system designed to eliminate undesirable RNAs in the cytoplasm (Vance and Vaucheret 2001; Waterhouse et al. 2001). Mechanistically similar processes exist in other eukaryotes (Bosher and Labouesse 2000; Hammond et al. 2001; Sijen and Kooter 2000). PTGS is triggered by double-stranded RNA which is "diced" into RNA species of approximately 21 to $23 \mathrm{nt}$. These short interfering (si)RNAs can act as guide sequences for specific cleavage of homologous RNAs (Hamilton and Baulcombe 1999; Hammond et al. 2001; Matzke et al. 2001; Zamore et al. 2000).

Most plant viruses have an RNA genome and replicate via double-stranded RNA intermediates, which are strong inducers of the RNA degradation system (Waterhouse et al. 1998). The resulting PTGS-type response is referred to as virus-induced gene silencing (VIGS) and is readily demonstrated with transgenic plants carrying a sequence with homology to the infecting virus. Under these conditions, viral RNA generally acts as both inducer and target of PTGS, which can result in elimination of the virus and recovery of the host (Baulcombe 1996, 1999; English et al. 1996; Goodwin et al. 1996; Marathe et al. 2000; Mueller et al. 1995). VIGS also can be induced in transgenic plants expressing a gene for a visible reporter such as $\beta$ glucuronidase (GUS) or green fluorescent protein (GFP) if the

Corresponding author: Véronique Brault; E-mail: brault@ colmar.inra.fr

This article is in the public domain and not copyrightable. It may be freely reprinted with customary crediting of the source. The American Phytopathological Society, 2002. challenge virus has been modified to contain a segment of the transgene sequence (Jones et al. 1999; Kjemtrup et al. 1998; Ruiz et al. 1998). In both situations, VIGS generally is accompanied by methylation within the transcribed portion of the silenced gene (English et al. 1996; Ingelbrecht et al. 1994; Jones et al. 1998, 1999). It has been proposed that such methylation is associated with production of aberrant transcripts which may be critical for maintenance of the silenced state (Jones et al. 1998, 1999; Vaucheret et al. 1998).

Here we report an example of VIGS in transgenic plants harboring a Beet western yellows virus (BWYV)-derived transgene. BWYV belongs to the genus Polerovirus in the Luteoviridae family, viruses whose members are restricted to the phloem tissue of the host plant and are strictly transmitted by an aphid vector (Gildow 1999; Herrbach 1999). We have expressed the coding sequence of the minor capsid protein (P74) of BWYV in transgenic Nicotiana benthamiana. P74 is known to play an important role in viral accumulation in plants (Brault et al. 1995; Mutterer et al. 1999) and in aphid transmission of the virus (Brault et al. 1995, 2000; Bruyère et al. 1997; Reinbold et al. 2001). Here we show that VIGS is specifically targeted against the P74 transgene mRNA in both vascular and nonvascular tissues but has, at most, only a small effect on accumulation of the invading virus in the phloem compartment.

\section{RESULTS}

Transgenic plants expressing the BWYV minor capsid protein $\mathbf{P 7 4}$.

The BWYV minor capsid protein P74 is a fusion protein between the major coat protein (CP; encoded by ORF3) and the readthrough domain (RTD; encoded by ORF5). P74 is synthesized during virus infection from a subgenomic RNA by occasional suppression of the TAG codon of ORF3. Transgenic plants expressing P74 were produced by Agrobacterium tumefaciens-mediated transformation of $N$. benthamiana with the T-DNA of pBi-bwP74 (Fig. 1). In the T-DNA, the leaky termination codon separating ORF3 and ORF5 was replaced by a TAC codon so that only P74 would be synthesized. The cDNA sequence was placed under transcriptional control of a $35 \mathrm{~S}$ promoter and a nopaline synthase (NOS) terminator sequence. Three GUS-positive plants (bwP74-B47, bwP74-B48, and bwP74-B49), which were found to express high levels of P74 by Western blot using an RTD-specific antiserum, were selfcrossed to obtain F1 progeny. F2 progeny from these lines were further selected for transgene expression by Western blot. The F1 and F2 progeny will be referred to as F1/bwP74-Bxx 
and F2/bwP74-Bxx, respectively. Typical expression of P74 in the transgenic plants is illustrated in Figure $2 \mathrm{~A}$, which shows that protein extracted from leaf tissue of F2/bwP74-B47 contained a prominent band of apparent molecular weight of 86 $\mathrm{kDa}$ (Fig. 2A, lanes 2 to 5) which co-migrated with P74 from virus-infected plants (lane 6) and which was absent from total protein extracts of a nontransgenic line (lane 1). Similar results were obtained with the other two lines (data not shown). None of the F1 and F2 progeny transgenic plants which expressed high levels of P74 exhibited unusual phenotypes.

Southern blot analysis was performed to determine the transgene copy number in F2/bwP74-B47. Genomic DNA was digested with EcoRI, which cuts three times in the RTD sequence and once after the NOS terminator (Fig. 1). Using a probe complementary to the $\mathrm{CP}$ sequence, hybridizing bands should include a border fragment or fragments extending from EcoRI at nucleotide 4,316 in the RTD sequence to an EcoRI site in the host DNA (Fig. 1). The hybridization pattern obtained from different F2/bwP74-B47 plants showed the presence of a border fragment of approximately 4,400 bp in some plants (Fig. 2B, lanes 1 to 5) and an additional border fragment of approximately 7,500 bp in other plants (Fig. 2B, lanes 2, 3, and 5). Similar patterns of hybridization have been obtained from F2/bwP74-B48 and -B49 (data not shown). This result indicates that the progeny are heterozygous and that different individuals contain one or two copies of the transgene.

\section{Expression of P74 in transgenic plants does not confer resistance to $B W Y V$.}

To determine if expression of P74 in the transgenic plants confers resistance to BWYV, transgenic plants were aphid-inoculated with BWYV and the plants were assayed by enzymelinked immunosorbent assay (ELISA) for virus infection 3 or 5 weeks later. The three F1 lines (F1/bwP74-B47, -B48, and -B49) as well as the F2 progeny F2/bwP74-B48 (seven lines) and F2/bwP74-B49 (five lines) were included in the resistance tests. Most of the transgenic and control plants became virus infected, but significant reduction in the rate of virus infection was found in transgenic compared with nontransformed plants (72.1 and $89.1 \%$ of infected plants, respectively) (Table 1). However, no significant difference in virus titer between infected transgenic and nontransformed lines was observed (Table 1). Similar results were obtained after aphid inoculation with BWYV of seven lines of F2/bwP74-B47 (data not shown). The ELISA-negative transgenic plants were assayed again for BWYV infection 8 weeks after inoculation and remained noninfected (data not shown).

Our inability to infect some of the transgenic plants could be due to occasional failure of the aphids to deliver sufficient in- oculum because the aphid inoculation procedure was not $100 \%$ effective for the nontransgenic lines treated in parallel. Alternatively, some of the noninfected transgenic plants could display either P74-mediated or somatic virus resistance. In order to further investigate the latter possibility, a number of the F2/bwP74-B49 plants which had escaped infection were vegetatively propagated and subjected to another aphid-inoculation test with BWYV. Four weeks after inoculation, most of these plants had become infected, indicating that the previous failure to achieve infection of these plants was not due to the presence of a resistance trait. However, since the second round of BWYV inoculation was performed with a higher number of aphids, we cannot exclude the possibility that the transgenic plants in question exhibit a low level of BWYV resistance which can be overcome by high inoculum pressure.

No significant difference in the behavior of the transgenic lines bwP74-B47, -B48, and -B49 was observed in the above experiments; therefore, we shall refer to all three lines from now on as P74-transgenic plants. Most of the following experiments employed line F2/bwP74-B47 plants but when other lines were used they gave similar results. The data obtained with the three lines are combined below.

\section{Infection of P74-transgenic plants with BWYV and related viruses induces elimination of the transgenic protein.}

Cross-sections of leaf petioles from transgenic plants were evaluated by tissue printing using the RTD-specific antiserum to determine the expression pattern of P74 under the control of the $35 \mathrm{~S}$ promoter. In mock-infected P74-transgenic plants, the central vascular bundle, the surrounding parenchyma cells, and the epidermal cells were heavily immunolabeled (Fig. 3A, panel 1T, dark staining). It is well known that the $35 \mathrm{~S}$ promoter is functional in most tissue types (Benfey et al. 1989; Odell et al. 1985), but it also has been shown to be particularly active within vascular cells along the internal and external phloem of stem (Jefferson et al. 1987). The lighter labeling in the parenchyma cells compared with vascular cells may be due in part to lower promoter activity, but could also be a consequence of the large unstained vacuoles present in the parenchyma cells. On the other hand, the petiole prints of nontransformed BWYV-infected leaves showed strong staining confined to the vascular bundle (Fig. 3A, panel 2nT), the cell types to which polerovirus infection is confined (D'Arcy and de Zoeten 1979; Mutterer et al. 1999; Shepardson et al. 1980). The prints of healthy nontransformed leaves did not exhibit any staining (Fig. 3A, panel $1 \mathrm{nT}$ ).

The effect of virus infection on localization of P74 in transgenic plants also was monitored by tissue printing. Petiole prints made 2 weeks postinoculation generally showed disap-

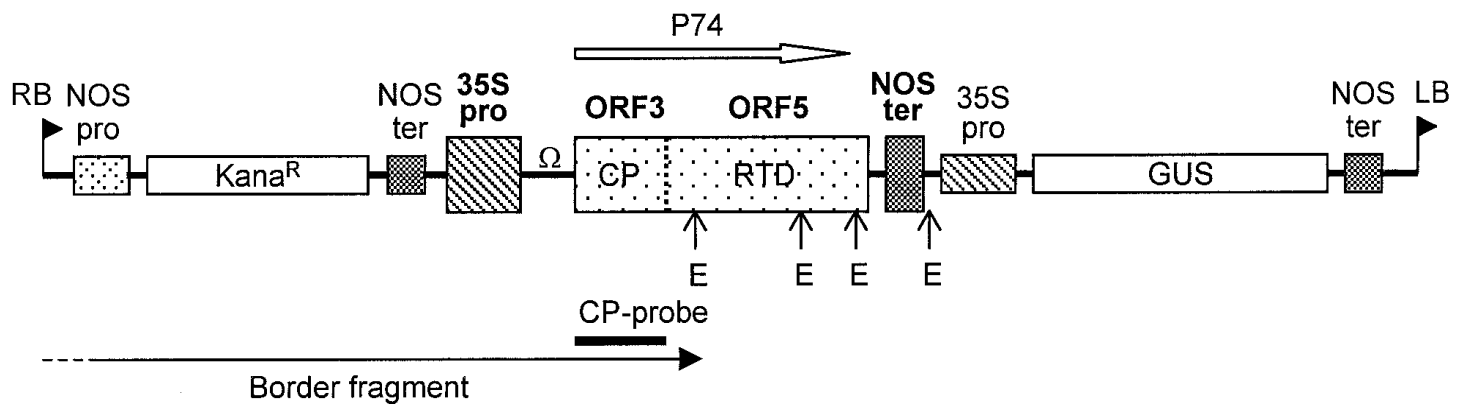

Fig. 1. Organization of the T-DNA fragment from pBi-bwP74 inserted in Nicotiana benthamiana. The following elements of the T-DNA are labeled: Right (RB) and left (LB) border of the T-DNA, nopaline synthase promoter (NOS pro), neomycin phosphotransferase gene (Kana ${ }^{\mathrm{R}}$ ), nopaline synthase terminator (NOS ter), 35S promoter (35S pro), $\beta$-glucuronidase gene (GUS), and Tobacco mosaic virus translation enhancer ( $\Omega$; Gallie et al. 1987). The coding sequences for the major coat protein (CP) and for the readthrough domain (RTD) are shown as dappled rectangles and the CP-RTD fusion protein P74 is represented by an open arrow above. $\mathrm{E}=$ EcoRI sites. Position of the CP-probe used in the Southern blot analysis is indicated. 
pearance of staining from sectors of the parenchyma (Fig. 3B, panel 2) and samples taken at later times (4 to 10 weeks) had lost staining over the entire parenchyma and epidermis, although the phloem tissue remained stained (Fig. 3A, panel 2T and Fig. 3B, panel 3). Extinction of the P74 signal was stable for at least 18 weeks after BWYV infection, the longest time tested (Fig. 3B, lane 4). When the transgenic plants were infected with a nonrelated virus, Grapevine fanleaf nepovirus (GFLV), no extinction of P74 was recorded (Fig. 3A, panel 3T). This indicates that disappearance of the transgenic P74 is not due to a general defense reaction of the host plant against virus infection.

Petiole prints of upper and lower leaves taken from transgenic BWYV-infected plants showed that disappearance of P74 occurred at all plant stages which could be monitored (data not shown), although it should be noted that the petioles of emerging leaves at the apex were too small to be examined by the tissue print technique. Disappearance of P74 following virus infection was not limited to petioles but also could be observed on leaf prints produced after removal of the lower epidermis. In the leaf prints of mock-inoculated transgenic plants, P74 could be faintly detected in cells over the whole leaf surface; whereas, in the virus-infected transgenic leaves, P74 generally was confined to regions adjacent to what appeared to be vein traces; that is, regions which presumably contain phloem cells (data not shown).
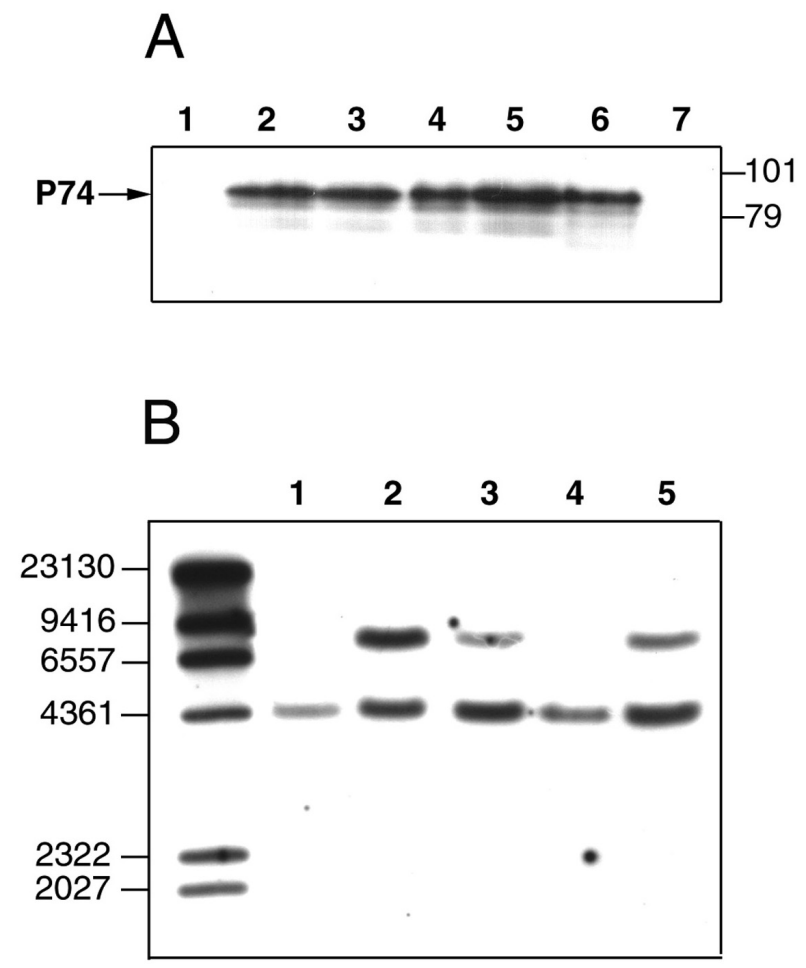

Fig. 2. Characterization of transgenic F2/bwP74 Nicotiana benthamiana plants. A, Western blot analysis of protein extracts prepared from a nontransgenic N. benthamiana (lane 1) and from four transgenic F2/bwP74B47 plants (lanes 2-5). As a control for P74 migration, protein extracts from Montia perfoliata infected with Beet western yellows virus (BWYV) (lane 6) or noninfected (lane 7) were loaded. P74 was detected with a BWYV anti-readthrough domain (RTD) serum (Reutenauer et al. 1993). The position of P74 is indicated to the left and two molecular weight markers (in kilodaltons) are shown to the right. B, Detection by Southern blotting of the T-DNA sequences inserted in the genome of the transformants derived from F2/bwP74-B47. Genomic DNA (10 $\mu \mathrm{g})$ was digested with EcoRI and hybridized with a probe complementary to the BWYV RNA nucleotides 3,563 to 4,107. Sizes (in base pairs) of ladder DNA fragments are indicated.
The foregoing observations indicate that BWYV infection silences transgenic P74 expression in parenchyma cells but it does not permit firm conclusions to be drawn concerning the origin of P74 in the phloem compartment. Thus, at this stage, we cannot say whether the P74 detected in the phloem cells of BWYV-infected transgenic plants is produced from the transgene or from the viral RNA (or from both). To investigate this question, P74-transgenic plants were graft inoculated with the BWYV mutant BWYV6.4, in which the RTD sequence has been deleted (Brault et al. 1995). Petiole tissue prints of $N$. benthamiana leaves revealed that BWYV6.4 provoked disappearance of the transgene P74 signal from the parenchyma (Fig. 3A, panel 4T). This was expected because the sequence homology between the CP sequence (ORF3) present in both the P74 coding region and the BWYV6.4 mutant is sufficient to trigger VIGS (see below). Importantly, P74 staining also was absent in the phloem bundle, which indicates that P74 produced from the transgene has disappeared in the phloem cells as well.

Infection of P74-transgenic plants with Potato leafroll virus (PLRV), another species in the Polerovirus genus, also provoked disappearance of P74 both in the parenchyma cells and in the phloem bundles of the petiole prints (Fig. 3A, panel 5T). PLRV did not significantly crossreact with the BWYV RTD antiserum, and no signal corresponding to the PLRV structural proteins was visible in the phloem bundle of PLRV-infected nontransgenic plants (Fig. $3 \mathrm{~A}$, panel $5 \mathrm{nT}$ ). There is, however, sufficient nucleotide sequence identity between ORF3 of

Table 1. Beet western yellows virus (BWYV) infection of transgenic plants after aphid inoculation

\begin{tabular}{|c|c|c|}
\hline Experiment, progeny & $\begin{array}{l}\text { No. plants infected/ } \\
\text { no. plants tested }\end{array}$ & $\begin{array}{l}\text { Virus titer in } \\
\text { infected plants }\end{array}$ \\
\hline \multicolumn{3}{|l|}{ Exp. 1, F1 } \\
\hline bwP74-B47 & $15 / 15$ & $1.45 \pm 0.19$ \\
\hline bwP74-B48 & $16 / 16$ & $1.28 \pm 0.26$ \\
\hline bwP74-B49 & $13 / 16$ & $1.14 \pm 0.23$ \\
\hline Nontransformed plants & $20 / 20$ & $1.42 \pm 0.17$ \\
\hline \multicolumn{3}{|l|}{ Exp. 2, F2 } \\
\hline bwP74-B48\#1 & $6 / 12$ & $1.02 \pm 0.38$ \\
\hline bwP74-B48\#2 & $7 / 12$ & $1.28 \pm 0.44$ \\
\hline bwP74-B48\#3 & $7 / 12$ & $1.09 \pm 0.46$ \\
\hline bwP74-B48\#4 & $9 / 12$ & $0.99 \pm 0.38$ \\
\hline bwP74-B48\#5 & $6 / 12$ & $0.67 \pm 0.19$ \\
\hline bwP74-B48\#6 & $9 / 12$ & $1.01 \pm 0.33$ \\
\hline bwP74-B48\#7 & $8 / 12$ & $0.95 \pm 0.27$ \\
\hline Nontransformed plants & $12 / 14$ & $1.08 \pm 0.46$ \\
\hline \multicolumn{3}{|l|}{ Exp. 3, F2 } \\
\hline bwP74-B49\#1 & $8 / 12$ & $1.32 \pm 0.38$ \\
\hline bwP74-B49\#2 & $9 / 13$ & $1.34 \pm 0.39$ \\
\hline bwP74-B49\#3 & $11 / 13$ & $1.05 \pm 0.27$ \\
\hline bwP74-B49\#4 & $7 / 13$ & $1.19 \pm 0.35$ \\
\hline bwP74-B49\#5 & $6 / 12$ & $1.23 \pm 0.37$ \\
\hline Nontransformed plants & $17 / 21$ & $1.61 \pm 0.55$ \\
\hline \multicolumn{3}{|l|}{ Exp. $4^{c}$} \\
\hline bwP74-B49\#1 & $3 / 4$ & $\ldots$ \\
\hline bwP74-B49\#2 & $1 / 1$ & $\ldots$ \\
\hline bwP74-B49\#3 & $1 / 1$ & $\ldots$ \\
\hline bwP74-B49\#4 & $3 / 3$ & $\ldots$ \\
\hline bwP74-B49\#5 & $5 / 5$ & $\ldots$ \\
\hline Nontransformed plants & $0 / 3$ & $\ldots$ \\
\hline
\end{tabular}

a Virus source was BWYV-infected plants. After a 24-h acquisition access period, 8 (F2 plants) to 15 (F1 plants) aphids were transferred to transgenic plants for an inoculation access period of 4 days. Plants were assayed by enzyme-linked immunosorbent assay (ELISA) 4 weeks (Exp. 1), 3 weeks (Exp. 2), and 5 weeks (Exp. 3) after aphid inoculation.

b Virus titer corresponds to the mean ELISA values from which the healthy control ELISA value has been subtracted.

${ }^{c}$ Some of the noninfected plants from Exp. 3 were propagated (Exp. 4) and further challenged by BWYV; 30 to 50 viruliferous aphids were used to inoculate each of these plants. 
PLRV and BWYV (Mayo and Ziegler-Graff 1996) to trigger VIGS (see below). Thus, the experiments with PLRV reinforce the conclusions obtained when BWYV6.4 was used to infect the P74-transgenic plants (i.e. polerovirus infection induces extinction of transgenic P74 in both the parenchyma and phloem compartments of the plants).

\section{VIGS is responsible for the disappearance} of transgenic P74 from the infected plants.

The disappearance of P74 from the transgenic plants in response to infection with wild-type BWYV, BWYV6.4, and PLRV can be readily understood in the context of VIGS because there is sequence homology between the various inducing viruses and the transgene. It cannot be ruled out from the above observations, however, that the disappearance of the transgene protein might, instead, be due to some hitherto unknown phenomenon involving infection-mediated inhibition of P74-transgene RNA translation or degradation of the protein.

To directly measure transgene mRNA levels in silenced plants, total RNA was extracted from leaves of mock-inoculated or virus-infected P74-transgenic plants and analyzed by Northern blot using an RTD-specific antisense RNA probe. It is important to note that much of the RNA in the extract will be of nonvascular origin because epidermal cells and various mesophyll cell types are much more abundant than phloem cells in leaves. The transgene mRNA was readily detectable in the mock-inoculated P74-transgenic plants (Fig. 4, lanes 1-4), where it had similar mobility to the subgenomic RNA produced during BWYV infection (Fig. 4, lane 12). Because of this, it was not possible to distinguish between the transgene mRNA and the viral subgenomic RNA in BWYV-infected transgenic plants. To overcome this difficulty, PLRV infection was used to induce VIGS of the P74 transgene. In PLRV-infected P74-transgenic plants, we observed a nearly complete disappearance ( $>95 \%$, evaluated by densitometry) of the transgene mRNA signal (Fig. 4, lanes 5-11), which indicates that the extinction of $\mathrm{P} 74$ provoked by virus infection is related to loss of the transcript rather than translational or post-translational down-regulation of P74 levels. Furthermore, a transcription run-on experiment conducted with nuclei extracted from BWYV-infected or noninfected P74-transgenic plants confirmed that disappearance of P74 did not correlate with a reduction of transcription of P74 transgene mRNA (Fig. 5A), reinforcing the hypothesis that expression of the transgene mRNA is inhibited at a step subsequent to transcription.

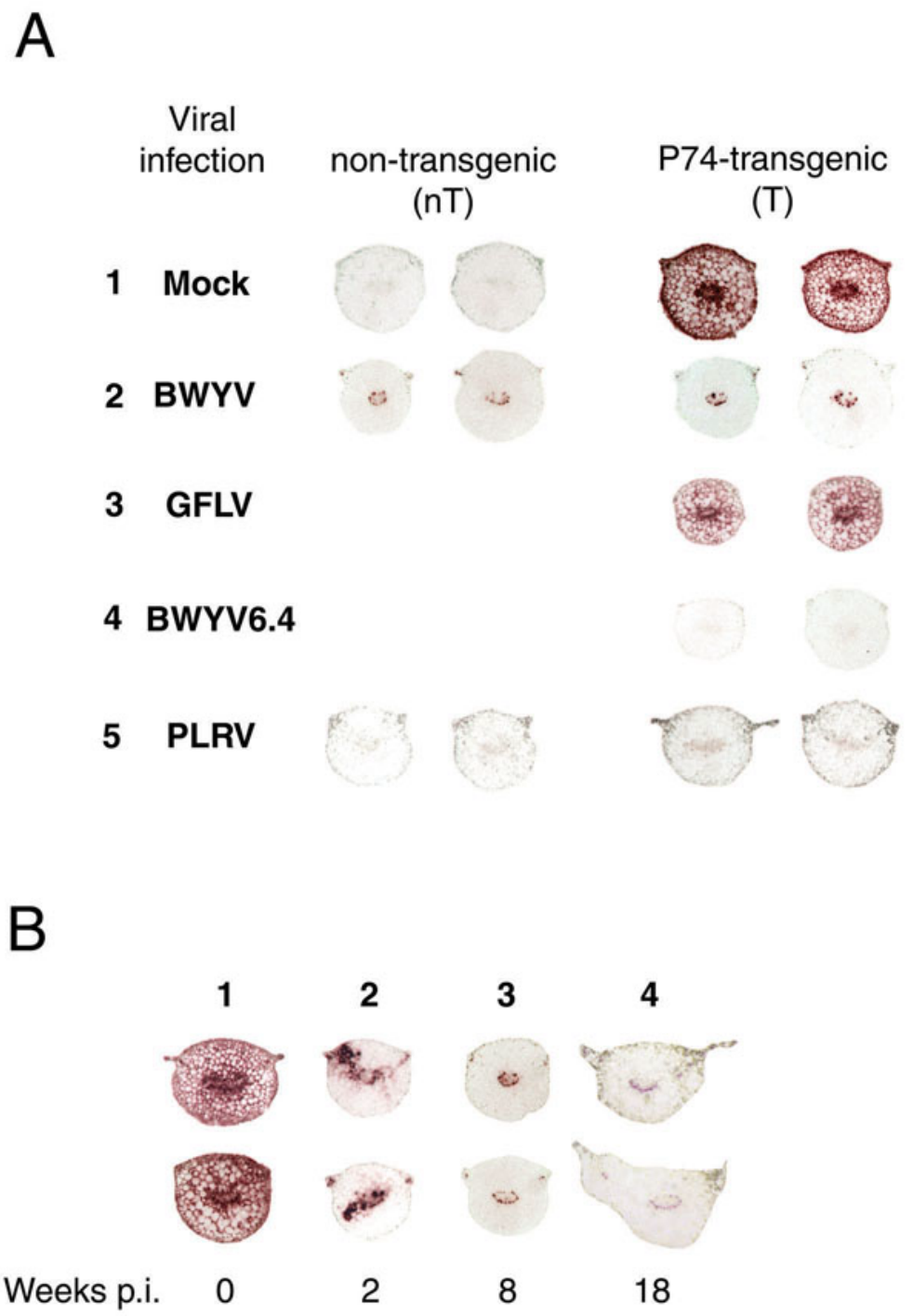

Fig. 3. Immunoprints of petiole sections of Nicotiana benthamiana developed with a Beet western yellows virus readthrough domain (BWYV RTD) antiserum. A, Immunoprints from nontransgenic (nT) or F2/bwP74 transgenic plants (T). Plants were either mock-inoculated (1) or infected with BWYV (2), Grapevine fanleaf nepovirus (GFLV)-13 (3), BWYV 6.4 (4), or Potato leafroll virus (PLRV)-NL (5). B, Immunoprints of F2/bwP74 transgenic plants infected with BWYV performed at various times postinoculation (p.i.). 
It is known that transgene-derived siRNAs of 21 to $23 \mathrm{nt}$ are generated in plants undergoing PTGS (Hamilton and Baulcombe 1999). These small RNAs are believed to be the specificity determinants of RNA silencing in virus-infected cells (Voinnet 2001). We have examined extracts of small RNA from leaves of PLRV-infected P74-transgenic plants using an antisense RNA probe specific for the BWYV RTD sequence. Transgene-derived small RNAs were detected in the leaf extracts of five PLRV-infected P74-transgenic plants (Fig. $5 B$, lanes 2-6) but not in an extract from a noninfected P74transgenic plant (Fig. 5B, lane 1) or in an extract of a PLRVinfected nontransformed plant (Fig. 5B, lane 7).

Taken together, the above findings represent strong evidence that VIGS is responsible for the PRLV infection-mediated disappearance of transgenic P74 from the nonvascular cells which constitute much of the tissue mass of leaves. We have no direct evidence that VIGS is also specifically implicated in the disappearance of transgenic P74 from the phloem compartment as well, but it is extremely likely that this is, in fact, the case. VIGS depends upon the presence of homology between the virus inducer sequence and the target transgene, and recently it has been shown that a stretch of sequence identity of $23 \mathrm{nt}$ is sufficient to trigger the phenomenon (Thomas et al. 2001). BWYV and PLRV P74 nucleotide sequences show 52.6\% similarity and there are numerous short stretches of identical sequence scattered throughout ORF3 and ORF5. In particular, two perfect matches of 23 nt located in a region of 69 residues in ORF3 could account for the ability of PLRV to induce VIGS. The BWYV6.4 and BWYV sequences are, of course, perfectly homologous to a third (BWYV6.4) or all (BWYV) of the transgene sequence. Therefore, it is highly likely that VIGS also is responsible for the disappearance of P74 induced by BWYV and BWYV6.4 infection of the P74-transgenic plants.

Methylation of the P74 transgene DNA accompanies VIGS.

To investigate the state of methylation of the P74 transgene DNA following VIGS, DNA samples were prepared from leaves of P74-transgenic plants 12 weeks following either mock-inoculation (nonsilenced plants) or inoculation with BWYV (silenced plants). It should be noted again that the DNA was extracted from total leaf tissue and, therefore, is derived from mesophyll and epidermal cells as well as phloem cells. DNA preparations were digested with several methylation-sensitive restriction enzymes (HaeIII, AluI, and Sau96I) and analyzed after gel-blot hybridization with a BWYV P74-specific probe. The pattern of hybridization obtained from DNA digested with HaeIII or Sau96I is presented in Figure 6B. Similar results were obtained with

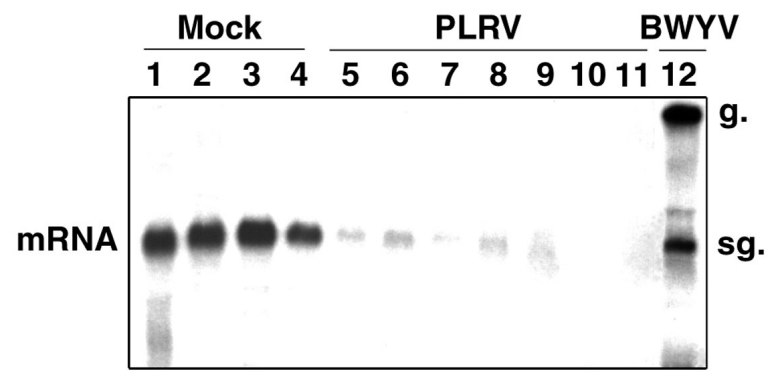

Fig. 4. Northern blot analysis of total RNA extracted from P74-transgenic Nicotiana benthamiana mock-inoculated (lanes 1-4) or infected with Potato leafroll virus (PLRV) (lanes 5-11) or Beet western yellows virus (BWYV) (lane 12). In each lane, $4 \mu \mathrm{g}$ of RNA was hybridized with a probe complementary to the sequence of the $33^{\prime}$-terminal part of the BWYV readthrough domain (RTD) (nucleotides 5,036 to 5,368). Exposure of lane 12 was three times shorter than the rest of the membrane. Positions of the transgenic mRNA and the BWYV genomic (g) and subgenomic (sg) RNA are indicated.
AluI (data not shown). The P74 transgene DNA from the nonsilenced plants was cleaved by each enzyme to produce the expected small fragments (Fig. 6A), except for those smaller than $0.15 \mathrm{~kb}$ which could not be visualized on the gel. Parallel digestion of DNA samples from the plants silenced by BWYV infection produced abundant larger species, corresponding to DNA fragments starting in the $35 \mathrm{~S}$ promoter upstream of P74 transgene DNA and ending in the downstream $35 \mathrm{~S}$ promoter (Sau96I) or in the GUS gene (HaeIII), as well as a number of weakly labeled smaller fragments, in particular in the case of Hae III digestion (Fig. 6B). This pattern of hybridization indicates that the transgene coding sequence is methylated during VIGS, whereas its promoter region is not. The additional weakly labeled fragments presumably result from incomplete methylation of the P74 DNA sequence.

\section{Effect of VIGS on accumulation of viral RNA.}

VIGS of a transgene mRNA generally is accompanied by suppression of RNAs sharing sequence homology with the transgene, notably the inducer RNA (Goodwin et al. 1996; Guo and Garcia 1997; Lindbo et al. 1993; Smith et al. 1994). To investigate the effect of silencing on viral RNA levels in our system, Northern blot analysis using BWYV or PLRV RNA-specific riboprobes was carried out on total RNA from a series of P74-

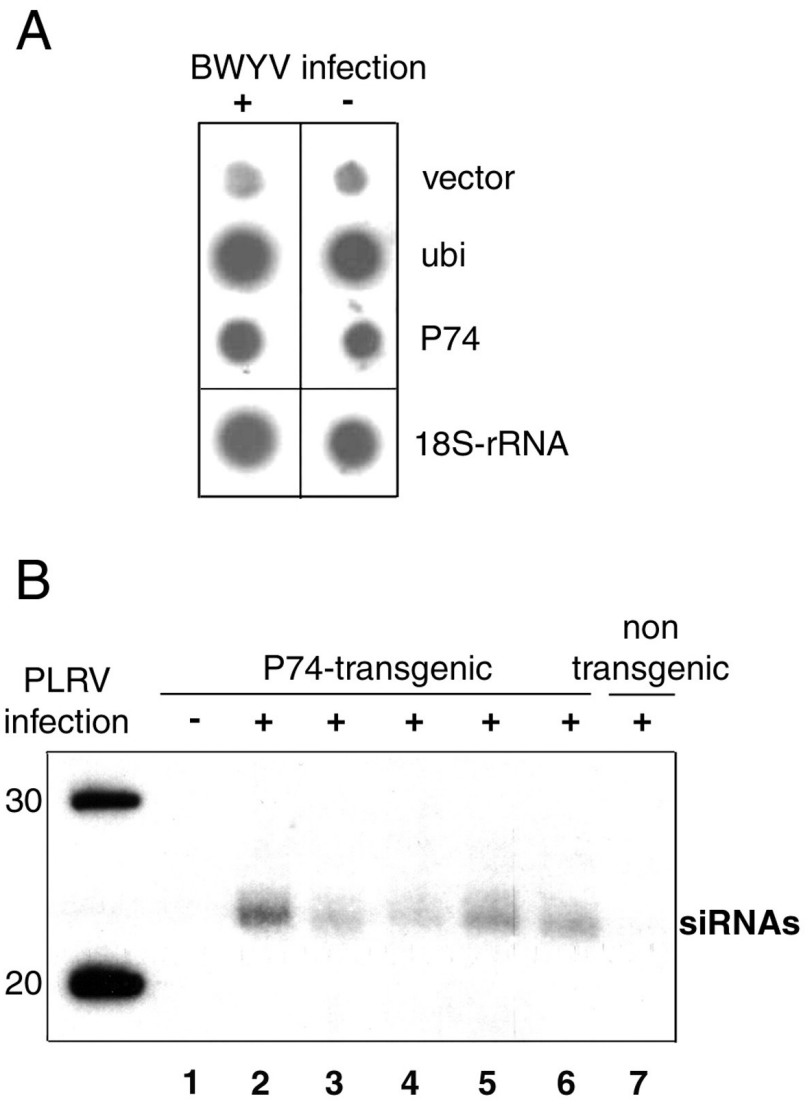

Fig. 5. A, Nuclear run-on analysis of transgene transcription in Nicotiana benthamiana mock-inoculated (-) or infected (+) with Beet western yellows virus (BWYV). Bluescript plasmid DNA (vector), Ubiquitin DNA sequence (ubi), P74 DNA sequence (P74), and 18S-rRNA cDNA (18SrRNA). Background signal for Bluescript vector is approximately $20 \%$ the level observed in the P74 spots. B, Northern blot analysis for detection of short interfering (si)RNAs. RNA was isolated from P74-transgenic (lanes 1-6) or nontransgenic (lane 7) $N$. benthamiana either mock-inoculated (lane 1) or infected with Potato leafroll virus (PLRV) (lanes 2-7). The probe is complementary to the $3^{\prime}$-terminal part of the BWYV readthrough domain (RTD) (nucleotides 5,036 to 5,368). Size markers (20- and 30-nt DNA oligomers) are shown to the left. 
transgenic plants 4 to 5 weeks after infection with either BWYV or PLRV. Progeny viral RNA was readily detected in all the BWYV- and PLRV-infected plants (Fig. 7A and B). In the BWYV-infected transgenic plants (Fig. 7A), accumulation levels of the progeny genomic and subgenomic RNA species were evaluated by densitometry in three independent experiments. They attained, on average, approximately $50 \%$ of the level of accumulation observed in the BWYV-infected nontransformed plants. Similar results were obtained when the plants were sampled 9 weeks after inoculation (data not shown). In the case of the PLRV-infected plants, no significant difference between progeny viral RNA levels in the transgenic and nontransgenic plants was observed (Fig. 7B). We conclude from these experiments that, although VIGS in the P74-transgenic plants reduces transgene mRNA levels by approximately 95\%, it has, at most, only a twofold effect on levels of the inducer viral RNA. This conclusion also is consistent with our observations that the P74transgenic plants are readily infected and can serve as an inoculum source for aphid transmission of the virus.

\section{DISCUSSION}

We present evidence here that the P74 transgene mRNA both within and outside of the phloem compartment is targeted for degradation by VIGS, whereas viral RNA in the phloem com- partment is, at most, only weakly affected by the silencing system. The mechanism by which the silencing system discriminates between the viral and transgene RNA remains obscure. One possibility is that the viral RNA (but not the transgene RNA) is protected from degradation by sequestration in replication or translation complexes, virions, or other virus-infectionspecific structures in the cytoplasm. Another possibility is that a virus-coded silencing suppressor protein is involved. It has been shown that a number of viruses, including potyviruses, cucumoviruses, sobemoviruses, and tombusviruses, encode proteins which can counteract PTGS (Li and Ding 2001; Voinnet et al. 1999). Recently, we have shown that P0, the $29-\mathrm{kDa}$ protein encoded by the 5'-proximal gene on BWYV RNA, displays strong silencing suppressor activity in a transient expression system (Pfeffer et al. 2002). P0 inhibited cell-autonomous PTGS but did not interfere with production, movement, and perception of the mobile silencing signal, at least in the assay system employed. Therefore, expression of this protein during virus infection would, as observed, not interfere with VIGS of the P74 transgene mRNA in nonvascular tissues. It would, however, be expected to counteract silencing in the phloem compartment where the virus and its gene products are confined. Therefore, the putative silencing suppression activity of virus-encoded P0 does not readily account for the observed discrimination between viral and transgene sequences in the phloem.

A

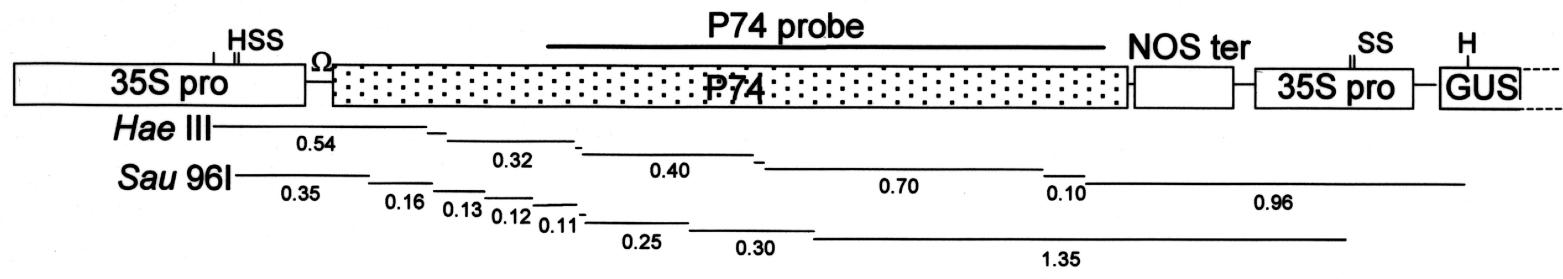

B

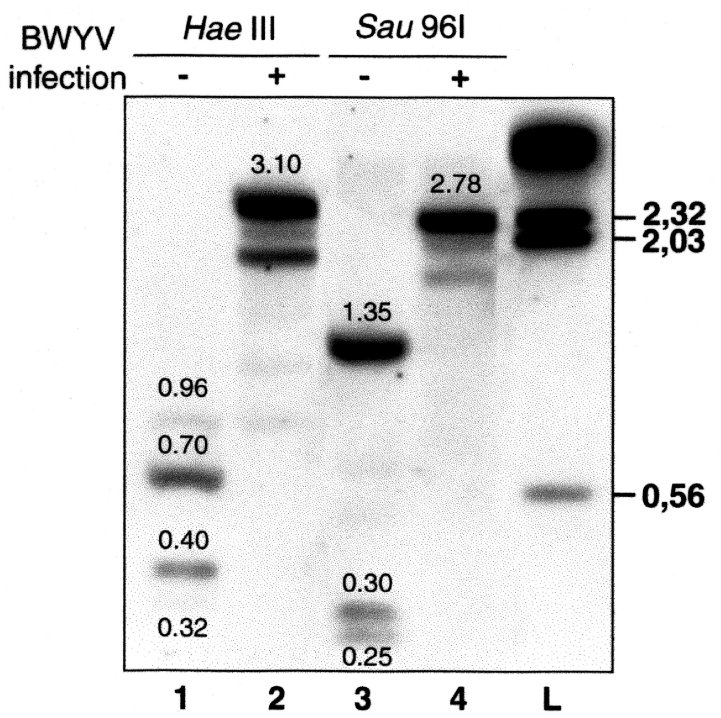

Fig. 6. Methylation associated with virus-induced gene silencing (VIGS) of the P74-transgene DNA. A, Structure of the P74 transgene is shown, including the 35S promoter (35S pro, from pMJD82; Dowson Day et al. 1994), the P74 coding sequence (P74), the nopaline synthase terminator (NOS ter), and the second 35S promoter (from pBiTC; Erhardt et al. 1999) of the adjacent $\beta$-glucuronidase (GUS) cassette. HaeIII and Sau96I restriction sites present in the 35S promoter or the GUS gene are marked above the corresponding boxes. Expected digestion products and their size in kilobases are shown below, except for those smaller than $100 \mathrm{bp}$. Note that the pattern of HaeIII restriction site differs between the two 35S promoters. The position of the P74 probe used in the Southern blot analysis in B is indicated. B, Southern blot analysis of genomic DNA samples from mock-inoculated (lanes 1 and 3) and silenced Beet western yellows virus (BWYV)-infected leaves (lanes 2 and 4). DNA samples were digested with HaeIII or Sau96I and hybridized with a P74 gene-specific probe. Sizes (in kilobases) of ladder (L) DNA fragments and expected DNA fragments generated by digestion are indicated. 
There have been several reports (Barker et al. 1993; Barker and Waterhouse 1999; Palucha et al. 1998; van der Wilk et al. 1991) describing PLRV-resistant transgenic potato plants transformed with the major PLRV coat protein sequence in sense or antisense orientations. The nature of the resistance was not definitely determined in these studies but an RNA-mediated resistance mechanism was thought to be involved. In view of these findings, further investigations are clearly in order to determine if transgenic plants expressing the BWYV major coat protein are similarly virus resistant or whether the differences between our observations and those reported for PLRV are related to the different virus-host combinations used.

\section{MATERIALS AND METHODS}

\section{Viruses and plants.}

The virus isolates were the following: BWYV-FL1 (Leiser et al. 1992), PLRV-NL kindly provided by H. van den Heuvel (van der Wilk et al. 1989), and GFLV-F13 from G. Demangeat. Purification of BWYV was essentially as described (van den Heuvel and Peters 1990), except that the final step was a 20to- $60 \%$ sucrose gradient.

The polymerase chain reaction (PCR) was used to generate a DNA fragment encoding the BWYV minor CP (P74). The resulting fragment contained both the $\mathrm{CP}$ and $\mathrm{RTD}$ sequences, but the suppressible termination codon separating ORF3 and ORF5 was replaced by a tyrosine codon (Reutenauer et al. 1993). The PCR fragment was inserted into pMJD82 (Dowson Day et al. 1994) so that the BWYV cDNA sequence was flanked on the $5^{\prime}$ side by a $35 \mathrm{~S}$ promoter and an omega $(\Omega)$ translation enhancer sequence and, on the $3^{\prime}$ side, by the NOS termination signal. The resulting transcription cassette was introduced into the binary vector pBiTC (Erhardt et al. 1999) to produce pBi-bwP74 (Fig. 1). N. benthamiana was transformed with $A$. tumefaciens LBA4404 containing the binary vector and transformed plants were regenerated by conventional procedures (Jefferson et al. 1987). Selection was for kanamycin resistance and GUS expression. Lines which were high expressers of P74 were identified by Western blot analysis of P74 in total leaf protein extracts using an RTD-specific antiserum (Reutenauer et al. 1993). The selected lines bwP74-B47, bwP74-B48, and bwP74$\mathrm{B} 49$, were self-crossed two times to obtain the $\mathrm{F} 2$ progeny on which experiments were performed unless otherwise indicated.

\section{Inoculation.}

Aphid inoculation of plants with BWYV and PLRV was performed after acquisition by second- to fourth-instar $M$. persicae larvae on either detached leaves or on purified virus by membrane feeding (Bruyère et al. 1997). In some cases, leaves of agroinfected N. clevelandii (Leiser et al. 1992) were notchgrafted to $N$. benthamiana root stock. Virus infection was routinely assayed by double-antibody sandwich ELISA (Herrbach et al. 1991) using a BWYV-, PLRV-, or GFLV-specific antiserum.

\section{DNA, RNA, and protein analysis.}

Genomic DNA was extracted from leaves with a DNeasy plant DNA extraction kit (Qiagen, France) according to the manufacturer's instructions and Southern blot analysis onto nylon membrane (Boehringer Mannheim, France) was performed as described (Boehringer Mannheim). The DNA probes used to detect the transgene sequence were complementary to ORF3-5 (nucleotides 3,563 to 4,107) or ORF5 (nucleotides 4,004 to 5,413) and were PCR-labeled with digoxygenin (Boehringer Mannheim).

RNA extraction from leaves was performed with a RNeasy Plant Minikit (Qiagen). Northern blot analysis was as described previously (Veidt et al. 1992) using either a BWYV- or
PLRV-specific ${ }^{32} \mathrm{P}$-labeled antisense RNA probe. For BWYV, the probe was complementary to the $3^{\prime}$-proximal 196 residues of the viral RNA or to nucleotides 5,036 to 5,368 (ORF5). For PLRV, the probe was complementary to nucleotides 1,021 to 1,404 of ORF1. Equal loading was controlled by visualization of the bands of ethidium bromide-stained ribosomal RNA on the gels and quantification of viral genomic RNA was performed using a Bio-Imaging analyzer (BAS 1000, Fujix).

Nuclei from leaves of noninfected and BWYV-infected transgenic $N$. benthamiana and ${ }^{32} \mathrm{P}$-labeled nuclear run-on transcripts were prepared essentially as described (Dehio and Schell 1994), except that the nuclei were harvested from the pellet after a percoll gradient centrifugation. Plasmid DNA (1 $\mu g$ ) containing a segment of the $N$. tabacum $18 \mathrm{~S}$ rRNA gene, and $4 \mu \mathrm{g}$ of DNA from plasmids containing either the N.tabacum ubiquitin U4 gene (obtained from P. Genschik), the BWYV P74 gene, or empty vector (Bluescript, Stratagene, Netherlands) were spotted in duplicate on two Hybond membranes (Amersham, France). After fixation of the DNA and prehybridization, the membranes were allowed to hybridize for $48 \mathrm{~h}$ with the radioactive transcripts obtained from $3 \times 10^{6}$ nuclei from either the infected or noninfected plants. Details concerning the prehybridization, hybridization, and membrane washing procedures were as described (Dehio and Schell 1994). The siRNAs were extracted essentially as described (Hamilton and Baulcombe 1999) and detected by Northern blot using a probe specific for BWYV ORF5 (nucleotides 5,036 to 5,368 ).

Tissue prints from petioles of $N$. benthamiana were produced by pressing the freshly razor-cut end of a petiole to nitrocellulose (BA85; Schleicher-Schuell, Germany). Subsequent treatment of the tissue prints was exactly as for a Western blot (Reutenauer et al. 1993) using an antiserum for the RTD (Reutenauer et al. 1993) as primary antiserum and goat anti-rabbit serum conjugated to alkaline phosphatase as the

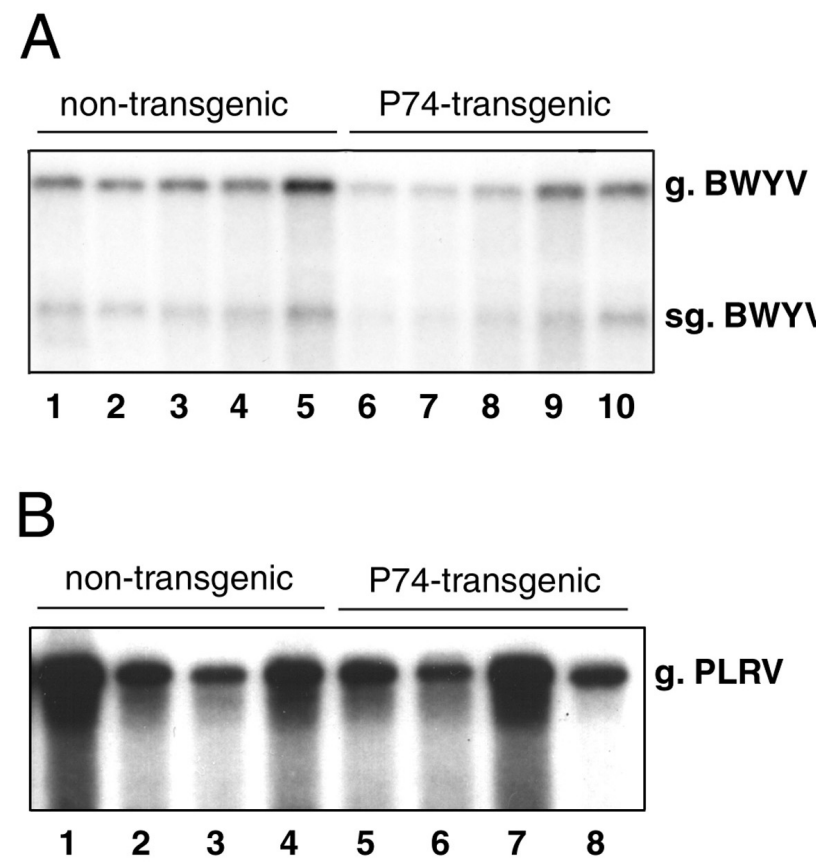

Fig. 7. Northern blot analysis showing viral accumulation in nontransgenic and P74-transgenic Nicotiana benthamiana infected with either A, Beet western yellows virus (BWYV) or B, Potato leafroll virus (PLRV). BWYV RNA was detected using a probe complementary to the 3'-terminal $196 \mathrm{nt}$ of BWYV and PLRV RNA with a probe complementary to nucleotides 1,021 to 1,404 of ORF1. Positions of corresponding genomic $(\mathrm{g})$ and subgenomic (sg) RNAs are indicated to the right. 
second antiserum. Staining for immobilized secondary antiserum employed the NBT/BCIP (Sigma, France). P74 expressed from the transgenic plants was detected in total protein extract by Western blot using the same RTD-specific antiserum.

\section{ACKNOWLEDGMENTS}

We thank Dirk Prüfer for help in plant transforming techniques, $H$. van den Heuvel for the gift of the PLRV-NL virus, and G. Demangeat for providing us with GFLV-F13. Ken Richards is acknowledged for helpful discussions. A visit by J. Mutterer to the Max Planck Institute (Köln, Germany) was funded by a French-German program (PROCOPE \#96101). This work was funded in part by the Biotechnology Program (BIO4-980374).

\section{LITERATURE CITED}

Barker, H., Reavy, B., Webster, K. D., Jolly, C. A., Kumar, A., and Mayo, M. A. 1993. Relationship between transcript production and virus resistance in transgenic tobacco expressing the potato leafroll virus coat protein gene. Plant Cell Rep. 13:54-58.

Barker, H., and Waterhouse, P. M. 1999. The development of resistance to luteoviruses mediated by host genes and pathogen-derived transgenes. Pages 169-210 in: The Luteoviridae. H. G. Smith and H. Barker eds. CAB International, Oxon, U.K.

Baulcombe, D. C. 1996. Mechanisms of pathogen-derived resistance to viruses in transgenic plants. Plant Cell 8:1833-1844.

Baulcombe, D. C. 1999. Viruses and gene silencing in plants. Arch. Virol. Suppl. 15:189-201.

Benfey, P. N., Ren, L., and Chua, N. H. 1989. The CaMV 35S enhancer contains at least two domains which can confer different developmental and tissue-specific expression patterns. EMBO (Eur. Mol. Biol. Organ.) J. 8:2195-2202.

Bosher, J. M., and Labouesse, M. 2000. RNA interference: Genetic wand and genetic watchdog. Nature Cell Biol. 2:E31-E36.

Brault, V., Mutterer, J. D., Scheidecker, D., Simonis, M. T., Herrbach, E., Richards, K., and Ziegler-Graff, V. 2000. Effects of point mutations in the readthrough domain of the beet western yellows virus minor capsid protein on virus accumulation in planta and on transmission by aphids. J. Virol. 74:1140-1148.

Brault, V., van den Heuvel, J. F. J. M., Verbeek, M., Ziegler-Graff, V., Reutenauer, A., Herrbach, H., Garaud, J-C., Guilley, H., Richards, K., and Jonard, G. 1995. Aphid transmission of beet western yellows luteovirus requires the minor capsid read-through protein P74. (Eur. Mol. Biol. Organ.) J. 14:650-659.

Bruyère, A., Brault, V., Ziegler-Graff, V., Simonis, M.-T., van den Heuvel, J. F. J. M., Richards, K., Guilley, H., Jonard, G., and Herrbach, E. 1997. Effects of mutations in the beet western yellows virus readthrough protein on its expression and packaging and on virus accumulation, symptoms, and aphid transmission. Virology 230:323-334.

D'Arcy, C. J., and de Zoeten, G. A. 1979. Beet Western Yellows Virus in phloem tissue of Thlaspi arvense. Phytopathology 69:1194-1198.

Dehio, C., and Schell, J. 1994. Identification of plant genetic loci involved in a posttranscriptional mechanism for meiotically reversible transgene silencing. Proc. Natl. Acad. Sci. U.S.A. 91:5538-5542.

Dowson Day, M. M., Ashurst, J. L., and Dixon, R. A. 1994. Plant expression cassettes for enhanced translational efficiency. Plant Mol. Biol. Rep. 12:347-357.

English, J. J., Mueller, E., and Baulcombe, D. C. 1996. Suppression of virus accumulation in transgenic plants exhibiting silencing of nuclear genes. Plant Cell 8:179-188.

Erhardt, M., Herzog, E., Lauber, E., Fritsch, C., Guilley, H., Jonard, G., Richards, K., and Bouzoubaa, S. 1999. Transgenic plants expressing the TGB1 protein of peanut clump virus complement movement of TGB1defective peanut clump virus but not of TGB1-defective beet necrotic yellow vein virus. Plant Cell Rep. 18:614-619.

Gallie, D. R., Sleat, D. E., Watts, J. W., Turner, P. C., and Wilson, T. M. A. 1987. The 5'-leader sequence of tobacco mosaic virus RNA enhances the expression of foreign gene transcripts in vivo and in vitro. Nucleic Acids Res. 15:3257-3273.

Gildow, F. E. 1999. Luteovirus transmission and mechanisms regulating vector specificity. Pages 88-113 in: The Luteoviridae. H. G. Smith and H. Barker, eds. CAB International, Oxon, U.K.

Goodwin, J., Chapman, K., Swaney, S., Parks, T. D., Wernsman, E. A., and Dougherty, W. G. 1996. Genetic and biochemical dissection of transgenic RNA-mediated virus resistance. Plant Cell 8:95-105.

Guo, H. S., and Garcia, J. A. 1997. Delayed resistance to plum pox potyvirus mediated by a mutated RNA replicase gene: Involvement of a gene silencing mechanism. Mol. Plant-Microbe Interact. 10:160-170.

Hamilton, A. J., and Baulcombe, D. C. 1999. A species of small antisense RNA in posttranscriptional gene silencing in plants. Science 286:950952.

Hammond, S. M., Caudy, A. A., and Hannon, G. J. 2001. Posttranscriptional gene silencing by double-stranded RNA. Nat. Rev. Genet. 2:110-119.

Herrbach, E. 1999. Vector-virus interactions. Introduction. Pages 85-88 in: The Luteoviridae. H. G. Smith and H. Barker, eds. CAB International, Oxon, U.K

Herrbach, E., Lemaire, O., Ziegler-Graff, V., Lot, H., Rabenstein, F., and Bouchery, Y. 1991. Detection of BMYV and BWYV isolates using monoclonal antibodies and radioactive RNA probes, and relationships among luteoviruses. Ann. Appl. Biol. 118:127-138.

Ingelbrecht, I., Van Houdt, H., Van Montagu, M., and Depicker, A. 1994. Posttranscriptional silencing of reporter transgenes in tobacco correlates with DNA methylation. Proc. Natl. Acad. Sci. U.S.A. 91:10502-10506.

Jefferson, R. A., Kavanagh, T. A., and Bevan, M. W. 1987. GUS fusions: $\beta$-Glucuronidase as a sensitive and versatile gene fusion marker in higher plants. EMBO (Eur. Mol. Biol. Organ.) J. 6:3901-3907.

Jones, A. L., Thomas, C. L., and Maule, A. J. 1998. De novo methylation and co-suppression induced by a cytoplasmically replicating plant RNA virus. EMBO (Eur. Mol. Biol. Organ.) J. 17:6385-6393.

Jones L., Hamilton, A. J., Voinnet, O., Thomas, C. L., Maule, A. J., and Baulcombe, D. C. 1999. RNA-DNA interactions and DNA methylation in posttranscriptional gene silencing. Plant Cell 11:2291-2301.

Kjemtrup, S., Sampson, K. S., Peele, C. G., Nguyen, L. V., Conkling, M. A., Thompson, W. F., and Roberston, D. 1998. Gene silencing from plant DNA carried by a Geminivirus. Plant J. 14:91-100.

Leiser, R. M., Ziegler-Graff, V., Reutenauer, A., Herrbach, E., Lemaire, O., Guilley, H., Richards, K., and Jonard, G. 1992. Agroinfection as an alternative to insects for infecting plants with beet western yellows luteovirus. Proc. Natl. Acad. Sci. U.S.A. 89:9136-9140.

Li, W. X., and Ding, S. W. 2001. Viral suppressors of RNA silencing. Curr. Opin. Biotechnol. 12:150-154.

Lindbo, J. A., Silva-Rosales, L., Proebsting, W. M., and Dougherty, W. G. 1993. Induction of a highly specific antiviral state in transgenic plants: Implications for regulation of gene expression and virus resistance. Plant Cell 5:1749-1759.

Marathe, R., Anandalakshmi, R., Smith, T. H., Pruss, G. J., and Vance, V. B. 2000. RNA viruses as inducers, suppressors and targets of posttranscriptional gene silencing. Plant Mol. Biol. 43:295-306.

Matzke, M., Matzke, A. J. M., and Kooter, J. M. 2001. RNA: Guiding gene silencing. Science 293:1080-1083.

Mayo, M. A., and Ziegler-Graff, V. 1996. Molecular biology of luteoviruses. Adv. Virus Res. 46:413-460.

Mueller, E., Gilbert, J., Davenport, G., Brigneti, G., and Baulcombe, D. C. 1995. Homology-dependent resistance: Transgenic virus resistance in plants related to homology-dependent gene silencing. Plant J. 7:10011013.

Mutterer, J. D., Stussi-Garaud, C., Michler, P., Richards, K. E., Jonard, G., and Ziegler-Graff, V. 1999. Role of the beet western yellows virus readthrough protein in virus movement in Nicotiana clevelandii. J. Gen. Virol. 80:2771-2778

Odell, J. T., Nagy, F., and Chua, N. H. 1985. Identification of DNA sequences required for activity of the cauliflower mosaic virus $35 \mathrm{~S}$ promoter. Nature 313:810-812.

Palucha, A., Zagòrski, W., Chrzanowska, M., and Hulanicka, D. 1998. An antisense coat protein gene confers immunity to potato leafroll virus in a genetically engineered potato. Eur. J. Plant Pathol. 104:287-293.

Pfeffer, S., Dunoyer, P., Heim, F., Richards, K. E., Jonard, G., and ZieglerGraff, V. 2002. P0 of Beet western yellows virus is a suppressor of posttranscriptional gene silencing. J. Virol. 76:6815-6824.

Reinbold, C., Gildow, F. E., Herrbach, E., Ziegler-Graff, V., Gonçalves, M. C., van den Heuvel, J. F. J. M., and Brault, V. 2001. Studies on the role of the minor capsid protein in transport of Beet western yellows virus through Myzus persicae. J. Gen. Virol. 82:1995-2007.

Reutenauer, A., Ziegler-Graff, V., Lot ,H., Scheidecker, D., Guilley, H., Richards, K., and Jonard, G. 1993. Identification of beet western yellows luteovirus genes implicated in viral replication and particle morphogenesis. Virology 195:692-699.

Ruiz, M. T., Voinnet, O., and Baulcombe, D. C. 1998. Initiation and maintenance of virus-induced gene silencing. Plant Cell 10:937-946.

Shepardson S., Esau K., and Mccrum R. 1980. Ultrastructure of potato leaf phloem infected with Potato Leafroll Virus. Virology 105:379-392.

Sijen, T., and Kooter, J. M. 2000. Posttranscriptional gene-silencing: RNAs on the attack or on the defense? BioEssays 22:520-531.

Smith, H. A., Swaney, S. L., Parks, T. D., Wernsman, E. A., and Dougherty, W. G. 1994. Transgenic plant virus resistance mediated by untranslatable sense RNAs: Expression, regulation, and fate of nonessential RNAs. Plant Cell 6:1441-1453. 
Thomas, C. L., Jones, L., Baulcombe, D. C., and Maule, A. J. 2001. Size constraints for targeting posttranscriptional gene silencing and for RNA-directed methylation in Nicotiana benthamiana using a potato virus X vector. Plant J. 25:417-425.

Van den Heuvel, J. F. J. M., and Peters, D. 1990. Transmission of potato leafroll virus in relation to the honeydew excretion of Myzus persicae. Ann. Appl. Biol. 116:493-502.

Van der Wilk, F., Huisman, M., J., Cornelissen, B., J., C., Huttinga, H., and Golbach, R. 1989. Nucleotide sequence and organization of potato leafroll virus genomic RNA. FEBS (Fed. Eur. Biochem. Soc.) Lett 245:51-56.

Van der Wilk, F., Willink, D. P-L., Huisman, M. J., Huttinga, H., and Golbach, R. 1991. Expression of the potato leafroll luteovirus coat protein gene in transgenic potato plants inhibits viral infection. Plant Mol. Biol. 17:431-439.

Vance, V., and Vaucheret, H. 2001. RNA silencing in plants-defense and counterdefense. Science 292:2277-2280.

Vaucheret, H., Béclin, C., Elmayan, T., Feuerbach, F., Godon, C., Morel, J.-B., Mourrain, P., Palauqui, J.-C., and Vernhettes, S. 1998. Transgene- induced gene silencing in plants. Plant J. 16:651-659.

Veidt, I., Bouzoubaa, S. E., Leiser, R. M., Ziegler-Graff, V., Guilley, H., Richards, K., and Jonard, G. 1992. Synthesis of full-length transcript of beet western yellows virus RNA: Messenger properties and biological activity in protoplasts. Virology 186:192-200.

Voinnet, O. 2001. RNA silencing as a plant immune system against viruses. Trends Genet. 17:449-459.

Voinnet, O., Pinto, Y. M., and Baulcombe, D. C. 1999. Suppression of gene silencing: A general strategy used by diverse DNA and RNA viruses of plants. Proc. Natl. Acad. Sci. U.S.A. 96:14147-14152.

Waterhouse, P. M., Graham, H. W., and Wang, M. B. 1998. Virus resistance and gene silencing in plants can be induced by simultaneous expression of sense and antisense RNA. Proc. Natl. Acad. Sci. U.S.A 95:13959-13964.

Waterhouse, P. M., Wang, M.-B., and Lough, T. 2001. Gene silencing as an adaptive defense against viruses. Nature 411:834-842.

Zamore, P. D., Tuschl, T., Sharp, P. A., and Bartel, D. P. 2000. RNAi: Double-stranded RNA directs the ATP-dependent cleavage of mRNA at 21 to 23 nucleotide intervals. Cell 101:25-33. 